\title{
電子材料ナノメー夕領域評価技術 光近接場の直観的描像
}

キーワード

光近接場, 近接場光学顕微鏡, 回折限界, 時間遅れの効果, Maxwell の境界条件, 双対な電磁ポテンシャル, 磁流
坂野斉

堀裕 和

山梨大学工学部

\section{1.はじめに}

近接場光学顕微鏡 (Near-field Optical Microscopy, NOM) は，走䅐型プローブ顕微鏡の一-種である. NOM で は, 光を入射場とし，小さな試料の散乱埸を近傍に近づけた 尖鋭なファイバープローブの先端で拾い上げて信号を得る. 特に,プロープ先端の幅と試料とプローブ先端との距晟が ともに光の波長より十分小さいような場合, NOM は回折限 界を越え, 光の波長以下の分解能をもつ. 通常の光学顕微鏡 では回折限界により，波長程度以下のスケールの構造を観 測できないことと対照的である，光の波長以下のスケール の物体を対象とできるNOMの技術の進展により, 光近接 場の利用の範国は，高密度の記憶媒体の開発や微細加工ま で㳂がりつつある.しかし，光近接埸の物理的描像や NOM の原理等の基本的事項に関しての腑に落ちる説明はないよ うである.この記事では，近接場／遠隔場の明確な定義のも と，光近接場の説明を直観的に行いたい. §1では基本的事 項について述べる。簡単な例を使って，回折限界，時間遅れ の効果を説明したのち，近接場／遠隔場の定義，理想的近接 場を規定する近接場条件の定義在述べる. §2で理想的近接 場で成立する準静的描像を直観的に説明する. §3では，近 接場と遠隔場を統一的に記述するため，双対なベクトルポ テンシャルを導入する.これをもとに双対な Ampere の法 則を導き，近接場から遠隔場へどのように物理が移行する かを直観的に説明をする．\$4でまとめと展望を述べる。

\section{1 身近な例: 超回折限界の観測}

まず，NOM が回折限界を越える観測ができることを身 近な例で示そう.小石を池に投げ入机ると，その小石の形に 拘らず円形の波紋を生ずる.よって，波源から遠方での観測 で小石の形を知ることはできない。これは，小石の大きさが 水面波の波長より小さいことが原因の”回折限界の存在”に よる.しかし，事のはじめから小石の形の情報が失われてい たわけではない，観測点を小石の落下点に十分近づければ， この情報は拾えるはずである.この観測法は NOMのもの である.次の §1.2では，これをもう少し正確に解析する。

\section{2 近接場/遠隔場と時間遅れの効果, 近接場条件} ここでは, ”時問遅れの効果”が波動の遠隔場と近接場を

An Intuitive Picture for Optical Near-field

By Itsuki Banno, Non-member and Hirokazu, Hori, Non-member

(Faculty of Engineering, Yamanashi University)

\section{图 1 简単な例}

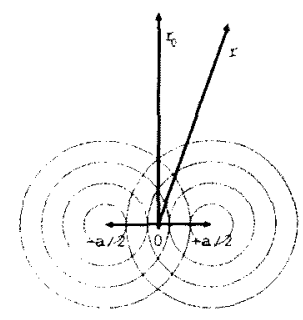

どのように特徵づけるかを概観し，近接場／遠隔場の明確な 定義をあたえる。一般に，波の散乱問題に执いて入射場の波 数を $k$, 散乱体試料の特徴的大きさを $a$, 散乱体試料から観測 点までの距離を $\boldsymbol{r}$ として典型的な次の 3 つの場合の違いを 考察しよう; (case1) $k r \gg k a \gg 1$, (case2) $k r \gg 1 \gg k a$, (case3) $k a<k r \ll 1$. これら 3 つの場合は, 時間遅れの効 果の現れ方が異なる.まず，時間遅れの効果之回折限界の関 係を簡単なスカラ一場の例で説明する。

図 1 のように, 3 次元空閒で $\mathbf{r}^{\prime}=-\mathbf{a} / 2$ と $\mathbf{r}^{\prime}=+\mathbf{a} / 2$ に同位相，同振幅，同角周波数 $\omega 02$ つの点波源; $\delta^{3}\left(\mathbf{r}^{\prime} \pm\right.$ $\mathbf{a} / 2) \exp \left(i \omega t^{\prime}\right)$ がある。今，aの方向ベクトル $\hat{a}$ は既知で あるが, $a=|\mathbf{a}|$ が未知であり，我々は，この未知量; $a$ を何 点かの観測点; $\mathbf{r}$ での測定から知りたいとする. $\omega / \boldsymbol{k}$ が位相 速度なので，ある時刻に $\mathbf{r}^{\prime}=\mp \mathbf{a} / 2$ の波源を出発した波は (伝搬に要する) 時間遅れ; $\Delta t(\mp \mathbf{a} / 2)=k|\mathbf{r} \pm \mathbf{a} / 2| / \omega の の$ ち，観測点; $\mathbf{r}$ に到着する.よって，位置; $\mathbf{r}$, 時刻; $t$ での観 測に奇与する 2 つ波源からの各部分波の振幅は次となる。

$$
\frac{e^{-i \omega(t-\Delta t(\mp \mathbf{a} / 2))}}{|\mathbf{r} \pm \mathbf{a} / 2|}=\frac{e^{-i \omega t+i k|\mathbf{r} \pm \mathbf{a} / 2|}}{|\mathbf{r} \pm \mathbf{a} / 2|}
$$

3 次元空間では，各波源からの部分波の”振幅の大きさ”は 流束の保存により，波源上観測点との距離に反比例し，"位 相”は時刻 $t^{\prime}=t-\Delta t(\mp \mathbf{a} / 2)$ における波源でのものに他 ならないことに注意すれば理解できよう。これは Huygens の原理の表現であり，また，Helmholtz 型方程式の Green 関数になっている， $\Delta t$ の表式より，時間遅れの効果とは， 本質的に波数依存性 $(k a, k r$ 依存性 $)$ であり，以下ではこの 意味で使う。

$(\mathbf{r}, t)$ での観測にかかる振幅 $A(\mathbf{r}, t)$ は，これらの部分波 の重ね合わせである. 


$$
A(\mathbf{r}, t)=\frac{e^{-i \omega t+i k|\mathbf{r}+\mathbf{a} / 2|}}{|\mathbf{r}+\mathbf{a} / 2|}+\frac{e^{-i \omega t+i k|\mathbf{r}-\mathbf{a} / 2|}}{|\mathbf{r}-\mathbf{a} / 2|}
$$

(case1), (case2) では, $r \gg a$ なので, 簡単な計算ののち eq.(1)は次のように評価される.

$$
A(\mathbf{r}, t)=\frac{e^{-i \omega t+i k r}}{r}\left(2 \cos (k a(\hat{\mathbf{r}} \cdot \hat{\mathbf{a}}))+\mathcal{O}\left(\frac{a}{r}\right)\right) .
$$

時間遅れの効果の $\mathrm{kr}$ 依存性亡 $\mathrm{ka}$ 依存性が分離され, 後者 に我々のほしい情報が含まれる. $\cos$ の中身は 2 つの部分 波の位相差であり，このような問題のときに我々が真っ先 に計算する量であろう. 今は, (case1),(case2),(case3)を同 じ立脚点から調べたいので位相差ではなく振幅の表式その ものに注目している。

(case1) では, $a$ は例えば次のようにしてわかる. $(\hat{\mathbf{r}} \cdot \hat{\mathbf{a}})=$ 0 なる方向の観測点 $\mathbf{r}_{0}$ では振幅の大きさが極大であるが, ここから $\mathbf{r}$ を $r=$ 一定の球面上を連続的にずらし次に振 幅の大きさが極大になる点を見つける.ここで, 位相差の大 きさが $2 \pi$ なので, $k a|\hat{\mathbf{r}} \cdot \hat{\mathbf{a}}|=2 \pi$, よって, $a=2 \pi / k /|\hat{\mathbf{r}} \cdot \hat{\mathbf{a}}|$ となる.このような求め方ができるのは, $k a \gg 1$ ゆえに 2 つの部分波の位相差の大きさが $2 \pi$ (以上)になる観測点が 必ず存在するからである。

(case2) では， $a$ を知ることができないことを示そう. eq.(2)から $a$ を知るためには $2 つ の$ 部分波の位相差の大 きさが $2 \pi$ 以上になる観測点が必要である; $k a|\hat{\mathbf{r}} \cdot \hat{\mathbf{a}}| \geq 2 \pi$. ここで, $|\hat{\mathbf{r}} \cdot \hat{\mathbf{a}}| \leq 1$ なので, $k a \geq 2 \pi$ が必要ということにな る.これが回折限界である. (case2) では $k a \ll 1$ なので, この回折限界のせいで $a$ を知り得ない，簡単にいえば, 2 つの波源が近すぎてあらゆる観測点; $\mathbf{r}$ で部分波が同位相 になってしまうのである.

以上の考察から, "回折限界" は $k r \gg 1$ 加》 $r \gg a の$ 条件下の概念であることを認識してほしい。

(case3) を考えよう. $k a<k r \ll 1$ で eq.(1) を評価する と次のようになる。

$$
\begin{aligned}
A(\mathbf{r}, t) & =e^{-i \omega t}\left(\frac{1}{|\mathbf{r}+\mathbf{a} / 2|}+\frac{1}{|\mathbf{r}-\mathbf{a} / 2|}\right) \cdots \cdots \\
& +\mathcal{O}(k a, k r) .
\end{aligned}
$$

主要項に時間遅れの効果 (波数依存性)がないことは, 系全 体が 1/4 波長以内に十分収まり波長を感じることができな いからである，また，回折限界にしばられずに $a$ を知り得 る. 例えば, $(\hat{\mathbf{r}} \cdot \hat{\mathbf{a}})=0$ なる方向の観測点 $\mathbf{r}_{0}$ で振幅の大き さが $A_{0}$ であるなら, $a=2 \sqrt{4-r_{0}^{2} A_{0}^{2}} / A_{0}$ と求まる.

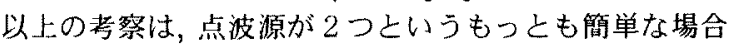
であるが, 波源が連続的に分布している場合も， $a$ を散乱体 試料の代表的スケールとすれば本質的な物理は同じである.

NOM のプローブ先端を観測点と考えれば, 光で (case3) に対応する観測が NOMによるものである. NOM では波数 に依存しない信号強度がえられ，また，回折限界にしばられ ないのは当然のことに思えてくる，ちなみに，回折限界にし

\begin{tabular}{|c|c|c|}
\hline 定義 & 回折限界 & 刉 \\
\hline $\begin{array}{c}\text { 遠隔場 } \\
k r \gg 1, r \gg a\end{array}$ & 50 & $\begin{array}{lc}k a \gg 1 \text { (case1) } & \text { 通常の光学䫁做鏡 } \\
k a \ll 1 \text { (case2) } & \text { Rayleigh 敬乱 }\end{array}$ \\
\hline $\begin{array}{c}\text { 近接場 } \\
1 \gg k r>k a\end{array}$ & なL & 近接場光学影微鏡 \\
\hline
\end{tabular}
ばられる通常の光学顕微鏡は (case1)に対応する. (case2) の光学的な例としては, Rayleigh 散乱があり, 遠方の観測

\section{表 1 近接場と遠隔場の定乘}

では，波長以下の領域に波源がいくつあるかを振幅の大き さから知り得るのみで, 波源の分布の詳紼は知り得ない.

我々は，回折限界にしばられる，(case1)，(case2)のよう な観測でえられる場を遠隔場, (case3) の観測でえられる場 を近接場と定義する. また, (case3)の条件を近接場条件と いうことにする. 以上をまとめると, 表1のようになる.

\section{2. 理想的光近接場の記述}

ここでは最も簡単と思われる近接場条件下での光近接場 の記述法とそれから得られる電場と電場強度の直観的描像を しめす.ただし，ここで議論する電場強度そのものが NOM の信号強度にはなっていない. 電場と NOM の信号強度の

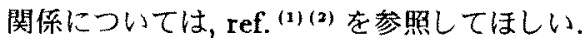

\section{1 準静的描像に基ずく電場}

光の入射場の波長より十分小さい誘電体による散乱電場 を十分近くで観測する場合を考える. 誘電体は，次のように 線形で局所的な分極をすると仮定する.

$$
\begin{aligned}
& \mathbf{P}(\mathbf{r}, t)=\epsilon(\mathbf{r}) \mathbf{E}(\mathbf{r}, t), \\
& \epsilon(\mathbf{r})= \begin{cases}\epsilon_{1} & \mathbf{r} \in \text { 試料内, } \\
\epsilon_{0} & \mathbf{r} \in \text { 試料外. }\end{cases}
\end{aligned}
$$

近接埸条件下では，注目している系全体が入射場の $1 / 4$ 波 長より十分小さいので系全体は, 空間的に一様な電場が時間 の経過とともにその強さを変化させていると感ずる.よっ て，近接場条件下の電磁波の散乱問題は，各時刻で，平板コ ンデンサー中にある誘電体の近傍の電場を求めるという問 題と同等である.この問題は, Coulombの法則 $\nabla \cdot D=0$ を用いて解けるはずである。即ち, Maxwell 方程式で時間 微分の項 (時間濐れの効果) を無視して電場部分のみを扱え ばよいことを意味する. (複素) 入射場に角振動数 $\omega$ の単色 光を用いるとすると, 線形の問題では, すべての場の時間依 存性に共通因子; $e^{-i \omega t}$ が現れるのでこれを省略して議論す る (時刻 $t=0$ での (複素) 場を求めると考えてもよい). こ のようにして求めた電場強度は, 実際の強度の長時間平均 したものに相当する(3).

まとめると, 近接場条件下の電磁波の散乱問題は, 時間避 れの効果が無視でき，準静電的問題に帰着する.

準静電的問題 (各時刻で静電的問題)の場合, 電磁場の最 小自由度はスカラーホホテンシャルである.これでかいた， Coulombの法則 (Poisson 万程式)が次である.

$$
\begin{aligned}
-\Delta \phi(\mathbf{r}) & =\frac{-1}{\epsilon_{0}} \nabla \cdot \mathbf{P}(\mathbf{r}) \ldots \ldots \ldots \\
& =\nabla \cdot\left(\frac{\epsilon(\mathbf{r})-\epsilon_{0}}{\epsilon_{0}}\right) \nabla \phi(\mathbf{r})
\end{aligned}
$$




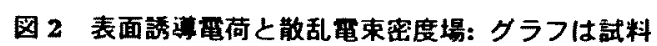
上空の走查線上の電場强度

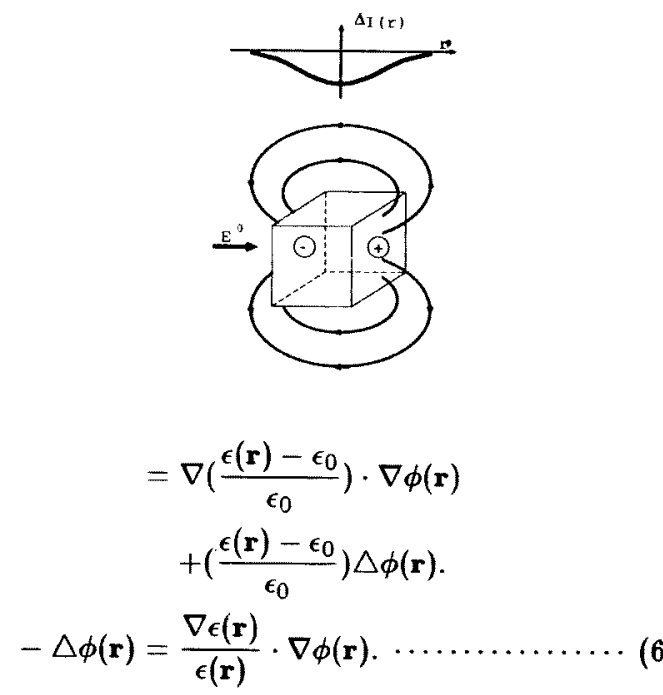

eq.(5)の第 4 辺第 2 項を第 1 辺に移行したのち，適当な因 子で割ると eq.(6)を得る. eq.(6)の右辺は, (誘導電荷密度 )$/ \epsilon_{0}$ であるが,これは, 試料表面でのみ 0 でない量; $\nabla \epsilon(\mathbf{r})$ を含むことから，表面で特異性をもつ．表面の源泉は波動の トビ即ち，Maxwellの境界条件をもたらす。

ここで, 近接場条件下゙では時間遅れの効果は小さくなる が, Maxwellの境界条件の効果は生き残ることに注意すべき である.これが光近接場に主要な寄与をし波数 (波長) 非依 存の淮静的描像をもたらす．この理由を明らかにするには, 時間遅れの効果を無視しない段階 (後にでてくる eq.(12)) で，境界条件の効果と時間遅孔の効果の大きさを比較する とよい，前者は，表面禎に比例した量で $(k a)^{2}$ の因子を含 む. 一方，後者は体皘に比例した量で $(k a)^{3}$ の因子を含む. これにより，近接場条件下では境界の効果が主要になる。

eq.(6)に基づき，近接場条件下での誘電体近傍の電場の 直観的描像を明らかにしよう. eq.(6) の右辺に含まれる 電場を次のように近似 (第 1 Born 近似)する. $-\nabla \phi=$ $\mathbf{E}=\mathbf{E}^{0}$ これにより (表面誘導電荷密度 $($ 面密度 $\left.)\right) / \epsilon_{0}$ は $\simeq\left(\epsilon_{1}-\epsilon_{0}\right) / \epsilon_{0} \mathbf{n}, \cdot \mathbf{E}^{0}$ とあたえられる $(\mathbf{n}$, は表面の外向き 単位法線ベクトル). あとは, Coulombの法則でこの源泉が つくり出す散乱場 $\Delta \mathbf{E}(\mathbf{r})=\mathbf{E}(\mathbf{r})-\mathbf{E}^{0}$ を想像すればよい. 簡単な方法は表面誘尊電荷密度のつくる電束を想像するこ とである. 電束の方向と本数が $\Delta \mathbf{E}$ の方向と振幅に比例し た量である．図2は直方体のある面に垂直な入射偏光べク トルの場合のボンチ絵である．電場強度の想像も容易であ る. 無次元相対電場強度は次であり，正 (負)であれば背景 より明るい(暗い)ことを表す

$$
\begin{aligned}
\Delta I(\mathbf{r}) & =\frac{\left|\mathbf{E}^{0}(\mathbf{r})+\Delta \mathbf{E}(\mathbf{r})\right|^{2}-\left|\mathbf{E}^{0}(\mathbf{r})\right|^{2}}{\left|\mathbf{E}^{0}(\mathbf{r})\right|^{2}} \\
& =\frac{2 \mathbf{E}^{0}(\mathbf{r}) \cdot \Delta \mathbf{E}(\mathbf{r})+|\Delta \mathbf{E}(\mathbf{r})|^{2}}{\left|\mathbf{E}^{0}(\mathbf{r})\right|^{2}}
\end{aligned}
$$

图 $3(\mathrm{a})$ 複雑な形状の試料 $\left(\epsilon_{1} / \epsilon_{0}=2.25\right)$ と入射電 場 (b) 最低次の近似による試料上空 $5 \mathrm{~nm}$ の走查面 上の電場强度
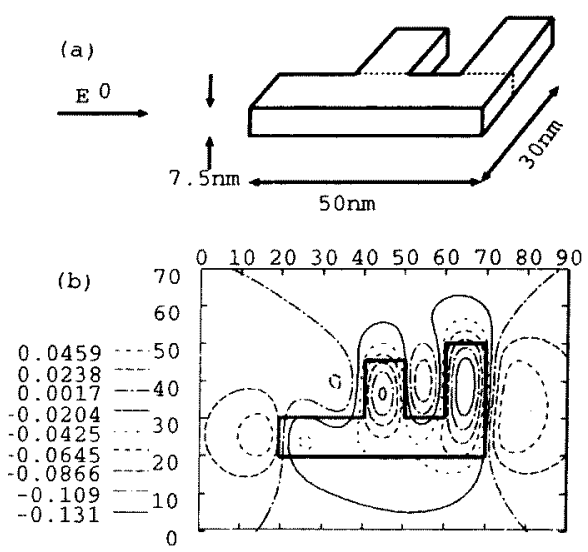

eq.(7) 第 3 辺で $|\Delta \mathbf{E}(\mathbf{r})| \ll\left|\mathbf{E}^{0}\right|$ とすれば，第 3 辺第 1 項の入射場と散乱場の干涉項が強度の強弱の原因であ る.ここで, eq.(7) は，遠隔場の観測での散乱強度の表式 $\Delta I(\mathbf{r})=|\Delta \mathbf{E}(\mathbf{r})|^{2}$ と異なることに注意しよう。遠隔場の 観測点は，入射場の可干渉な領域にないためである．近接場 では入射場と散乱場は干渉する。詳しくは ref. (1)(2)。

近接場特有の干涉項を考えよう. 例えば，図 2のような微 小な直方体の誘電体試料に光が当たった場合を考える. 観 測点 $\mathbf{r}$ が試料直上であれば，人射場と散乱場が反平行であ り，相対強度は背景強度 0 より小さくなる (暗くなる).

試料の形状が複雑であっても同様である。試しに，図 3(a) のような試料に虔光ベクトルが試料長手方向で, 十分大き な波長の光を当てた場合を考えよう. 表面誘導電荷密度を 第 1 Born 近似で見積もり，試料の $5 \mathrm{~nm}$ 上空での面上での 電場強度の計算結果が図 3(b) である。これを直観的に理 解するには図3(a) の点線にそって試料を 3 つの直方体に分 け，それぞれの散乱電場を図 2 の要領で想像する.このと き， $\mathbf{E}^{0} の$ 向に長い直方体から出る電束は遠力をまするこ とに注意. そして，3つの散乱電場を重ね台わせて $\Delta \mathbf{E}$ と し，最後に $\mathbf{E}^{0}$ との干涉を考えればよい、rにより，入射場 $\mathbf{E}^{0}$ と散乱場 $\Delta \mathbf{E}$ の内積の符号が変わり, 背景強度より明る いか暗いかきまる。

実は，図 3(a) の試料に関しては O.J.Martin らにより， 入射場の波長を $633 \mathrm{~nm}$ として, 時間遅れの効果までフルに 考慮した計算がなされている(1). 3 次元の源泉と, 界面で の誘電率の急峻かつ連続的资化を用いていて, 基本的には 伝統的な計算方法といえる

彼らの計算条件では，近接場条件が十分満たされている ので，我々の準静的描像に基づく結果と比較できる、実際， 図3(b)は，学生の演習問題程度のごく簡単なプログラムで 計算したものだが，彼らの対応する結果上非常によい一致 をしている.また，彼らの論文の fig.1(c)，(d) は入射場の波 
数ベクトルの方向は異なるものの偏光ベクトルは共通であ る場合だが,これらがほとんど同じ強度分布を与えている。 彼らは議論していないが，このことは波数非依存の淮静的 描像がこの系で成立していることの証拠である.

eq.(6)は，低次の近似により直観的理解を得るだけでな く高次の近似により精密な数値計算をするためにも有用で ある.この式により厄介ものの Maxwell の境界条件を表面 の特異的源泉に肩代りさせ掑動論的に扱える.また, 源泉が 2 次元的であり体皘中の誘導電荷密度がないことは, 計算 の量とコーディングの手間を著しく減らしてくれる。我々 の方法 ${ }^{(6)}$ では，正の大きな誘電率の試料から，金属のよう な負の大きな誘電率の試料まで計算可能であった．また, 物 体の形状が複雑であっても, Maxwell の境界条件を正確に 合わせることは容易であった。

§2をまとめる．近接場条件下では，時間遅れの効果は小 さくなるが, Maxwell の境界条件の効果は生き残る。後者 は波数に依存せず (準静的であり) 回折限界とは無関係であ る.また，近接場条件下の直観的描像を明らかにした。

\section{3. 近接場之遠隔場の統一的記述}

いままで，時間遅れの効果を無視できる近接場条件下; $k a<k r \ll 1$ での光近接場を扱ってきた。ここでは，ま ず，誘電体と光の系を記述するのに都合のよい”双対な電 磁ポテンシャル”を導入し，これを用いて隼近接場条件下 (sub-wavelength region) $k a<k r \leq 1$ での，近接場から 遠隔場へどのように移行するかの直観的描像を示す。

潐近接場条件 (sub-wavelength region) $k a<k r \leq 1(<$ $0.5 \pi)$ では試料と観測点を含む系は $1 / 4$ 波長以内におさま り，小さな時間逮れの効果が存在する.

\section{1 双対なベクトルポテンシャル}

我々の扱う系では，外電荷密度，外電流密度はなく，誘 導電荷密度，誘導電流密度があるだけである．この場合の Maxwell 方程式は次である.

$$
\begin{aligned}
& \nabla \cdot \mathbf{B}(\mathbf{r}, t)=0, \nabla \times \mathbf{E}(\mathbf{r}, t)+\partial_{t} \mathbf{B}(\mathbf{r}, t)=\mathbf{0} \\
& \nabla \cdot \mathbf{D}(\mathbf{r}, t)=0, \nabla \times \mathbf{H}(\mathbf{r}, t)-\partial_{t} \mathbf{D}(\mathbf{r}, t)=\mathbf{0}
\end{aligned}
$$

また,物質の方程式は次である。

$$
\begin{aligned}
& \mathbf{B}(\mathbf{r}, t)=\mu_{0} \mathbf{H}(\mathbf{r}, t)+\mathbf{M}(\mathbf{r}, t), \\
& \mathbf{D}(\mathbf{r}, t)=\epsilon_{0} \mathbf{E}(\mathbf{r}, t)+\mathbf{P}(\mathbf{r}, t) .
\end{aligned}
$$

ここで, eqs.(8)-(9)に，双対対称性があることに注意する. 即ち, 次のような, 電気的量と磁気的量の入換えに対して 方程式系全体は不変である。

$\begin{array}{ccccc}\text { 電気的量 } & \text { 磁気的量 } & & \text { 磁気的量 } & \text { 電気的量 } \\ \mathbf{D} & -\mathbf{H} & \Longrightarrow & \mathbf{B} & \mathbf{E} \\ \mathbf{E} & \mathbf{B} & \Longrightarrow & -\mathbf{H} & \mathbf{D} \\ \mathbf{P} & \mathbf{M} & \Longrightarrow & \mathbf{M} & \mathbf{P} \\ -\epsilon_{0} & -\mu_{0} & \Longrightarrow & \mu_{0} & \epsilon_{0}\end{array}$

さて, Maxwell 万程式系のもうひとつの特徴は電磁場の最
小自由度は $\mathbf{E} や \mathbf{B}$ ではなく, $\mathbf{B}=\nabla \times \mathbf{A}, \mathbf{E}=-\partial_{t} \mathbf{A}-\nabla \phi$ で定義される電磁ポテンシャル $\mathbf{A}, \phi$ であることである.こ の通常の電磁ポテンシャル $\mathbf{A}, \phi$ は, 磁気的応答があって $\mathbf{M} \neq \mathbf{0}$, 電気的応答がない $\mathbf{P}=\mathbf{0}$ とき，特に便利である (超伝導体を除いてこのような物質はないようだが).この 場合, Maxwell 方程式 eqs.(8) から放射ゲージの電磁ポテ ンシャルの波動方程式が導かれる. 界面領域を含む，空間全 域で放射ゲージが有効であることに注意.

$$
\begin{aligned}
\nabla \times \nabla \times \mathbf{A}(\mathbf{r}, t) & +\epsilon_{0} \mu_{0} \partial_{t}^{2} \mathbf{A}(\mathbf{r}, t) \\
& =\nabla \times \mathbf{M}(\mathbf{r}, t), \\
\nabla \cdot \mathbf{A}(\mathbf{r}, t) & =0, \\
\phi(\mathbf{r}, t) & =0 .
\end{aligned}
$$

今の場合, 電磁場の源泉は (磁化電流) $\times \mu_{0}=\nabla \times \mathbf{M}$ 亡 いう横ベクトル場なので, 電磁場の最小自由度として横べ クトル場 $\mathbf{A}$ のみであること(放射ゲージがとれること)は 自然である.

ここで，我々の扱いたい系の物質 (誘電体) は，上の物質 と双対な物質で, 電気的応答があって $\mathbf{P} \neq \mathbf{0}$, 磁気的応答が ない $\mathbf{M}=\mathbf{0}$ とみなせるものである. Maxwell 方程式と物 質の方程式 eqs.(8)-(9) の双対対称性に注目すると，誘電体 と光の系には次で定義される双対な電磁ボテンシャルを導 入するのが自然である(日) $; \mathbf{D}=\nabla \times \mathbf{C}, \mathbf{H}=\partial_{t} \mathbf{C}+\nabla \chi$.

eq.(10)を双対変換; $(\mathbf{A}, \phi, \mathbf{M}) \Longrightarrow(\mathbf{C}, \chi, \mathbf{P})$ すれば, 双 対な電磁ポテンシャル $\mathbf{C}$ の従う波動方程式が得られる.

$$
\begin{aligned}
\nabla \times \nabla \times \mathbf{C}(\mathbf{r}, t) & +\epsilon_{0} \mu_{0} \partial_{t}^{2} \mathbf{C}(\mathbf{r}, t) \\
& =\nabla \times \mathbf{P}(\mathbf{r}, t), \\
\nabla \cdot \mathbf{C}(\mathbf{r}, t) & =0 \\
\chi(\mathbf{r}, t) & =0 .
\end{aligned}
$$

誘電体と光の系の電磁場の最小自由度は，放射ゲージの 双対な電磁ポテンシャルであり，その源泉は(分極磁流 )$\times\left(-\epsilon_{0}\right)=\nabla \times \mathbf{P}$ である.これは (磁化電流 $) \times \mu_{0}=\nabla \times \mathbf{M}$ の双対な量である.

$\mathbf{P}$ をq.(4)で定義される誘電関数で与え, 波数 $k=\omega / c=$ $\omega\left(\epsilon_{0} \mu_{0}\right)^{1 / 2}$ の単色光を入射場として, $\S 2$ 亡同様の考元方で 時刻 $t=0$ の場の量を考えると, eq.(11)は，次のように なる。

$$
\begin{aligned}
\nabla \times \nabla \times \mathbf{C}(\mathbf{r}) & -k^{2} \mathbf{C}(\mathbf{r}) \cdots \cdots \ldots \ldots \\
& =-\hat{V}_{s}[\mathbf{C}](\mathbf{r})-\hat{V}_{v}[\mathbf{C}](\mathbf{r}), \\
\hat{V}_{s}[\mathbf{C}](\mathbf{r}) & =-\frac{\nabla \epsilon(\mathbf{r})}{\epsilon(\mathbf{r})} \times \nabla \times \mathbf{C}(\mathbf{r}), \\
\hat{V}_{v}[\mathbf{C}](\mathbf{r}) & =-\left(\frac{\epsilon(\mathbf{r})}{\epsilon_{0}}-1\right) k^{2} \mathbf{C}(\mathbf{r}) .
\end{aligned}
$$

源泉は, Maxwell の境界条件を担う (表面磁流) $\times\left(-\epsilon_{0}\right)=$ $-\hat{V}$ ，上時間遅的の効果を担う (体皘磁流) $\times\left(-\epsilon_{0}\right)=-\hat{V}_{v}$ に分けられる，後者が時間遟れの効果であることは $\hat{V}_{v}$ が波 数 $k$ に依存していることからわかる.また，時間遅れの効 
图 4 微小な立方体による光の散乱: 試料上空 $0.5 a$ の走查面上での觉場强度

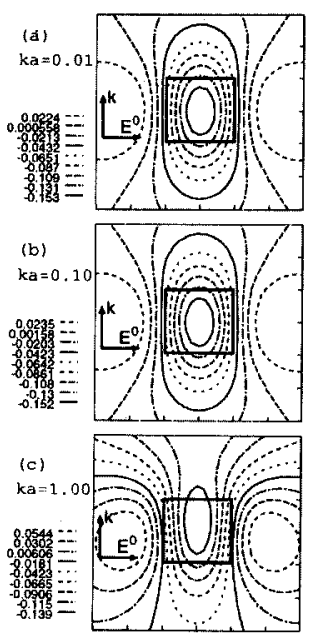

果は eq.(12) の左辺第 2 項にもある. eqs.(11)-(12)は, 近 接場から遠隔場まで有効で, 誘電体と光の系で一般的に用 いることができる汎用性を持つ. 特に，以下で示すように， 近接場から遠隔場へ描像がどのように推移するかを考察す るために役立つ.

一一般に物理では最小自由度で記述することによって，数 值計算の利便性や，直観的理解が得やすくなる. §2の場合も そうであった。しかしながら,一般的な教科書では, 真空中 の電磁場の記述には, 最小自由度として電磁ポテンシャル を導入するが, 反射, 屈折のような, 物質と光の系での現象 ではこれを用いない。この理由は，物質界面での波動のト ビ, 即ち, Maxwell の境界条件のせいである. 実は, eq.(6) や eq.(11)の右辺の源泉には, Maxwell の境界条件の代償 として, 超関数の積を含み, 数学的困難が生ずるのである.

我々の方法では，これを飼い慣らし，摄動的に Maxwell の境界条件が考慮できるのであるが、ここでは詳細は省略 し，值観的理解に的をしぼることにする.

\section{2 双対な Ampere の法則}

準近接場条件下での一辺 $a$ の立方体試料の近接場の強度 を様々な $k a$ に対して eq.(12) をもとに高次の Born 近似 で数值計算した予備的な結果が図 4 である，入射場(の偏 光ベクトル)はマップの横軸に平行, 波数ベクトルは縦軸上 方に向いている. 観測点は立方体の上空 $0.5 a$-の平面上にあ る. 等高線の数值は eq.(7) で定義される無次元相対強度で あり，正 (負) であれば背景より明るい(暗いことを表す。

これらの図の特徵を 2つあげる.

• $k a=0.01$ と $k a=0.10$ の 2 つ図の試料近傍では等 高楾の形だけでなく数值まで一致している (有効数字; 小数点以下第 2 位まで一致している).

- $k a=1.00$ の図で試料の入射方向後方の強度が小さく なる(暗くなる).

\section{图 5 双対な Ampere の法則 (a) ルーブ流が生む 䉓束密度場 (b) 直線磁流力゙生む電束密度場}

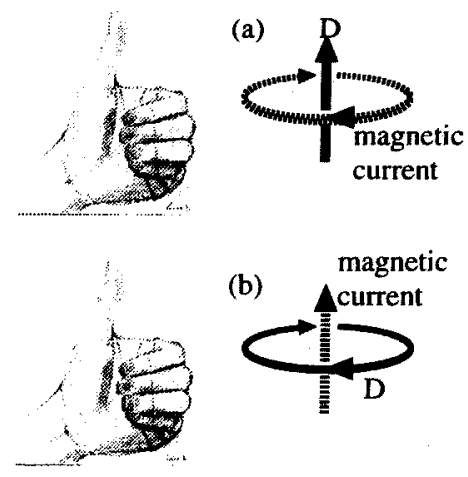

これらの準近接場条件下での特徵を直観的に理解するため に, eq.(12) の右辺と左辺第 2 項を第 1 Born 近似で評価 する;

$$
\begin{aligned}
\nabla \times \mathbf{D}(\mathbf{r}) & =\cdots \cdots \cdots \cdots \cdots \cdots \cdots \cdots \cdots \cdots \cdots \cdots \cdots \\
& -\hat{V}_{\mathrm{o}}\left[\mathbf{C}^{0}\right](\mathbf{r})-\hat{V}_{v}\left[\mathbf{C}^{0}\right](\mathbf{r})+k^{2} \mathbf{C}^{0}(\mathbf{r}) .
\end{aligned}
$$

ここで, $\mathbf{D}(\mathbf{r})=\mathbf{D}^{0}(\mathbf{r})+\Delta \mathbf{D}(\mathbf{r})$ とし, $\nabla \times \mathbf{D}^{0}(\mathbf{r})=$ $k^{2} \mathbf{C}^{0}(\mathbf{r})$ を eq.(13) から差し引くと次式を得る.

$$
\nabla \times \Delta \mathbf{D}(\mathbf{r})=-\hat{V}_{\boldsymbol{s}}\left[\mathbf{C}^{0}\right](\mathbf{r})-\hat{V}_{v}\left[\mathbf{C}^{0}\right](\mathbf{r})
$$

この式は 右辺の - $\epsilon_{0}$ (磁流密度) が電束密度場をつくると いう双対な Ampere の法則を表している. 定常電流を源泉 とした Ampere の法則は $\nabla \times \mathbf{B}=\mu_{0}$ (電流密度) であり， 高校では右手を用いて流れと場の関係を想像するよう教え られる. 双対な法則では右辺にマイナス符号があるので流 れと場の大雑把な関係を想像するのには左手が役立つ. 図 5に双対な Ampere の法則の左手をたよりにした運用の仕 方を 2 種説明してあるので確認してほしい.

まず，準近接場条件下; $k a<k r \leq 1$ で $\epsilon_{0}$ (表面磁流 密度 (面密度) ) はおよそ $\left(\epsilon_{1} / \epsilon_{0}-1\right) \mathbf{n}, \times \mathbf{D}^{0}, \epsilon_{0}$ (体積磁 流密度) はおよそ $-\left(\epsilon_{1} / \epsilon_{0}-1\right) k^{2} \mathbf{C}^{0}$ と見積もられる。こ れらを (時刻 $t=0$ で) 図示すると図 6 のようになる. $\mathbf{D}^{0}(\mathbf{r})=\nabla \times \mathbf{C}(\mathbf{r})=i \mathbf{k} \times \mathbf{C}^{0}(\mathbf{r})$ に注意. また, 準近接場 条件下では，時間遅れの効果が少しあり，立方体の入射面前 面の $\mathbf{D}^{0}(\mathbf{r})$ と後面の $\mathbf{D}^{0}(\mathbf{r})$ では, 後者の方がすこし振幅が 小さい. よって, 前面で上方に向かう表面磁流密度が後面 で下方に向かうものより大きい. 体積磁流はこれを補償す るように上方から下方に流れる。これにより磁流密度場全 体は横ベクトル場となり, 非物理的な磁荷の出現を免れて いる. 次に上の 2 種の磁流のつくる散乱場を考え, 特徵 (1), (2)を説明する.

特徽 (1) の条件, $k a=0.01,0.10$ では, 体積磁流の担う 時間遅れの効果は小さく, 表面のループ磁流の担う境界の 効果が主要である. 図 5(a) の双対な Ampere の法則によ 
图 6 （a）表面誘導磁流之散乱疍束密度場，(b) 体皘 颜道磁流之散乱电束密度場

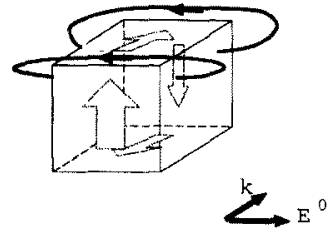

(a)

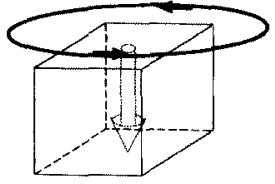

(b)
り，電束のできかたがわかる，ところで，このループ磁流が 電気双極子と等価 ことの双対) なので, この電束の様子は，図 2 そのものであ る. すなわち, §2の近接場条件下; $k a<k r \ll 1$ での波数 非依存または準静的描像のために $k a$ が異なっても同じ電 場強度のマップが現れるのである。

特徵 (2)の説明のために観測面上での準近接場条件下で の磁流がつくる場を大雑把に考えてみよう. 図 5(a)の双対 なAmpereの法則によれば，表面磁流密度は観測面上に図 6(a) のような散乱場 $\Delta \mathbf{E}_{\mathbf{2}}(\mathbf{r})$ をつくる。一方，図 5(b) の 双対な Ampereの法則によれば，体積磁流密度は観測面上 に図 6(b) のような散乱場 $\Delta \mathbf{E}_{v}(\mathbf{r})$ をつくる. 散乱場はこ れら 2 項の和 $\Delta \mathbf{E},(\mathbf{r})+\Delta \mathbf{E}_{v}(\mathbf{r})$ であるが, 入射の前面で は 2 項は弱め合い，後面では 2 項が確実に強めあう。

次に，場の強度 eq.(7) を考える. 場の強度を決めるのは 入射場と散乱場の干渉項であることに注意しよう，前面で の散乱場の方向は微妙だが，後面に関しては，確実に入射場 に反平行となる. よって，後面近傍の場の強度は負となる (背景より暗くなる).これが特徵 (2) の説明である.

一般に時間遅れの効果による体皘磁流は後方の散乱場を 入射場を打ち消すようにつくり，場の強度を弱めることが いえる.これは本質的に”影”であり特徽 (2) は試料の後 方に影ができはじめたことを意味する。

以上が，近接場から遠隔場への過渡的状況の直観的理解 である. NOMの信号にどのように時間遅れの効果が現れ るかは，まだ実験的にチェックされていないようである.\$3 では，近接場と遠隔場を統一的に报える理論的枠組を提案 し，近接場から遠隔場への物理的描像の移行を直観的に説 明した。

\section{4. まとめと展望}

この記事では, 古典電磁気学の枠組のなかで時間遅れの 効果とMaxwell の境界条件の効果を軸に光近接場を論じ, 以下のことを示した.

- 近接場条件下では, 時間遅れの効果は消え, Maxwell の 境界条件の効果のみ生き残る。この境界の効果注波数 に依存せず，淮静的描像をもたらす。NOM が回折限 界にしばられないのはこのためである.

・光上誘電体の系を扱うには, 通常の電磁ポテンシャルよ
り双対な電磁ポテンシャルがよい，後者では放射ゲー ジが採用でき最小自由度で電磁場の散乱を記述できる.

・準近接場条件下において見積もられた磁流から，双対 な Ampereの法則により電束密度場および電場強度を 想像できる，近接場から遠隔場への過渡的状況として， 時間遅れの効果のため影ができはじめる様子を確認し た. 時間遅れの効果が小さい沖えに電束という概念が 有効になり, 直観的理解が容易になる.

展望としては, 次を挙げる.

・磁気光学効果や非線形光学効果等が光近接場でどうな るのか

- 光近接場特有の量子效果はあるのか

この記事の内容に関する研究をするにあたり，東工大 大 津 元一博士, 京大 北野 正雄博士, 国際基督教大学北原 和 夫博士, ソウル大学 W.Jhe 博士, また, 遠藤 英裕博士と議 論し，助言，提案を賜わりました.お礼申しあげます．また， 図の製作では，坂野住野氏が協力してくれました。

(平成 11 年 8 月 10 日受付)

\section{文献}

(1) I. Banno, H. Hori, and T. Inoue, Optical Review 3, 454 (1996).

（2）坂野觕，堀裕和 双対的Ampereの法則とNOM 像（大津 元一，河 田聡緾，近接場ナノフォトニクスハンドフック $\mathrm{pp} 240$,オプトロ ニクス社 1996)

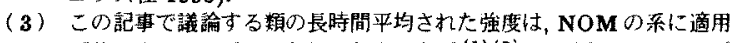
可能である (ただし，強度の表式の変更 ${ }^{(1)(2)}$ が必要). NOM のフ ローフの走查の特徽的速さは光の周期にくらベ十分痋心からである。

(4) J. F. Martin, C. Girard, and A. Dereux, Phys. Rev. Lett. 74, $526(1995)$.

(5) I.Banno, H.Hori, M.Kitano and K.Kitahara 投稿予定

(6) M.Ohtsu and H. Hori, "Near-Field Nano-Optics", Plenum Publ. Corp., New York, 1999.

坂 野 (非会員) 山梨大学工学部電気電子システム工学 科助手, 理学修士. 1987 年東京大学大学院理学系研究科(化学専攻) 修 士課程終了, 1991 年大阪大学大学院基磷工学研究科(物性物理工学棠 攻) 退学, 分子科学研究所技官. 1993 年上り現職. 専門は電磁気学, 物 性物理学.

堀裕 和 (非会員) 山梨大学工学部電気電子システムム」学 科助教授，工学愽士. 1983 年京都大学大学院工学研究科 (電子工学) を 䅂えて山梨大学工学部講師，1986 年より現睵.1988-89 年ワシントン 大学客員准教授 (物理学) 克門は量子エレクトロニクス，近接埸光学 など. 